\title{
The Intensity of PLA2R and C4d Immunoexpression in Primary Membranous Nephropathy
}

\author{
(1) Deniz Filinte, ${ }^{1}$ (1) Hakkı Arıkan, ${ }^{2}$ (1) Mehmet Koç, ${ }^{2}$ (1) Handan Kaya, \\ (1) İshak Çetin Özener, ${ }^{2}$ (1) Gamze Akbaş
}

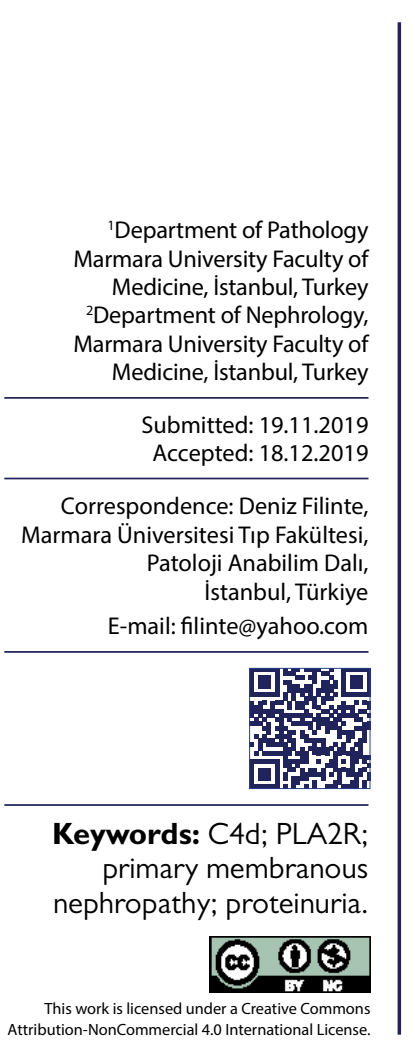

\begin{abstract}
Objective: Antibodies against the phospholipase A2 receptor (PLA2R) on podocyte membranes result in the formation of immune complexes that cause loss of function of the glomerular basement membrane in primary membranous nephropathy (PMN). It has also been demonstrated that there is a deposition of complement $4 d$ (C4d) in the glomeruli in PMN. The present study aims to evaluate PLA2R and C4d immunoexpressions in PMN cases and search the correlation with the clinical parameters.
\end{abstract}

Methods: In this study, clinicopathological data and paraffin-embedded specimens were collected from $5 \mathrm{I}$ patients. The formalin-fixed paraffin-embedded tissues were stained using routine hematoxylin-eosin, periodic acid-Schiff, and silver methenamine stains and immunostained for anti-PLA2R and C4d. Ten normal kidney tissues and 10 focal segmental glomerulosclerosis (FSGS) cases were selected as controls for PLA2R and C4d immunoexpression.

Results: Of the PMN cases, 5 I (100\%) cases were positive for PLA2R, including 15 (29\%) cases that scored $2+$, and $36(71 \%)$ cases that scored $3+$. Forty of the 5 I cases $(78 \%)$ were positive for C4d. The percentages of cases staining positively for C4d, per scoring group, were as follows: $31(61 \%)$ cases faintly $(I+)$ positive and $9(18 \%)$ cases moderately $(2+)$ positive. No strong positivity was observed. All of the control cases (100\%) were negative for PLA2R and C4d. There was no statistically significant difference between the intensity of the staining of PLA2R and the staining of C4d, proteinuria levels, creatinine levels, and complement 3 (C3) positivity. Similarly, there was no statistically significant difference between the intensity of the staining of $C 4 d$ and proteinuria levels, creatinine levels, and $C 3$ positivity.

Conclusion: Immunohistochemical detection of PLA2R and C4d is a safe and easy method for the diagnosis of PMN. In cases where fresh tissue is not available for the detection of $\operatorname{lgG}$ and $\mathrm{C} 3$ using the immunofluorescence method, positivity for PLA2R and C4d with immunohistochemistry may be beneficial for the diagnosis of PMN.

\section{INTRODUCTION}

Membranous nephropathy (MN) is the leading cause of nephrotic syndrome in the adult population. ${ }^{[l-4]}$ The disease is characterized by immune complex deposition on the outer aspect of the glomerular basement membrane. This deposition causes loss of function of the glomerular filtration barrier, which results in proteinuria. ${ }^{[2-4]}$ Traditionally, membranous nephropathy has been classified as primary or secondary membranous nephropathy. In $70-80 \%$ of the cases, there is no known etiology. If a secondary cause cannot be identified, this group is classified as "primary membranous nephropathy" (PMN). If MN is associated with a clinical condition, such as malignant tumors, autoimmune diseases, viral or bacterial infections (hepatitis B, syphilis) or drug intoxication, the disease is termed as "secondary membranous nephropathy". $[3,5,6]$

In situ immune complexes are formed due to the presence of antibodies against podocyte proteins. This issue has been determined to cause $\mathrm{MN}{ }^{\left[{ }^{7]}\right.}$ In $70 \%$ of the adult patients, PLA2R on podocytes has been demonstrated as a target antigen in PMN. ${ }^{[8]}$ PLA2R appears to be a causative antigen of PMN in most of adults ${ }^{[3,6,8-17]}$ and some pediatric populations. ${ }^{[18]}$

The pathogenesis of $\mathrm{MN}$ is mediated by the in situ formation of immune deposits, with the resulting activation of the complement. C4d is a fragment of complement 4 (C4) that is generated during activation of the classical complement or lectin pathways. Studies of C4d have focused on 
transplant biopsies as an indicator of acute humoral rejection, and very few studies have analyzed C4d in MN. However, in these studies, it has been shown that there is C4d deposition in the glomeruli in PMN ${ }^{[19-22]}$ In addition, it has been demonstrated that there is a positive correlation between the serum levels of PLA2R autoantibodies and the degree of proteinuria, severity of the disease, and loss of kidney function. It has also been demonstrated that followup testing of serum levels of PLA2R autoantibodies is useful for the prediction of recurrence of the disease. ${ }^{[1,9,23-29]}$

The present study aims to evaluate PLA2R and C4d immunoexpressions in PMN cases and search the correlation with the clinical parameters.

\section{MATERIALS AND METHODS}

Clinicopathological data and paraffin-embedded specimens were collected from 5 I patients (25/26 M/F; median age 50.7 years, range 19-75 years) who underwent renal biopsy in our department (Istanbul, Turkey) between 2000 and 2014. This study was approved by the local ethics committee. All cases were older than 18 years of age and clinical presentation and laboratory findings, such as proteinuria $(\mathrm{g} / 24-\mathrm{h})$ and serum creatinine $(\mathrm{mg} / \mathrm{dl})$, were documented in all cases (Table I). Patients with proteinuria ( $\geq 3.5 \mathrm{~g} / 24-\mathrm{h}$ ) were screened for secondary conditions by obtaining a complete clinical history, physical examination, and serologic tests for systemic lupus erythematosus, hepatitis B and C, HIV, as well as screening for malignancies.

Ten normal kidney tissues and 10 focal segmental glomerulosclerosis (FSGS) cases were selected as controls for PLA2R and C4d immunoexpression. The renal biopsies were stained with hematoxylin and eosin (H\&E), periodic acid-Schiff (PAS), periodic acid methenamine silver (Gomori PAMS), and Masson's trichrome. Morphological findings of the cases were mainly diffuse thickening of the glomerular basement membrane in light microscopic examination (Fig. Ia-c) and subepithelial IgG and C3 deposition in immunofluorescence examination. Data on the immunofluorescence examination for $\operatorname{lgG}, \mathrm{C} 3$, IgA, Clq, fibrinogen, kappa, and lambda light chain antibodies were available on the pathology report of the cases.

\section{Immunohistochemistry}

Three micron thick sections of the total 7I formalin-fixed, paraffin-embedded tissues were immunostained for antiPLA2R (CL0474; Atlas Antibodies) and C4d (Polyclonal; CellMarque). Immunostaining was performed with Leica Bond-Max automatic immunostainer (Leica, Bannockburn, IL) following 82 minutes of incubation at room temperature in a Bond ${ }^{\mathrm{TM}}$ Polymer Refine Detection Kit (Leica Biosystems, Catalog No. DS9800).

Slides were examined blindly by two independent pathologists under a light microscope (Olympus BX53, Tokyo, Japan), and microscopic images were obtained on a light microscope linked to a digital camera (Olympus SCI00, Tokyo, Japan).

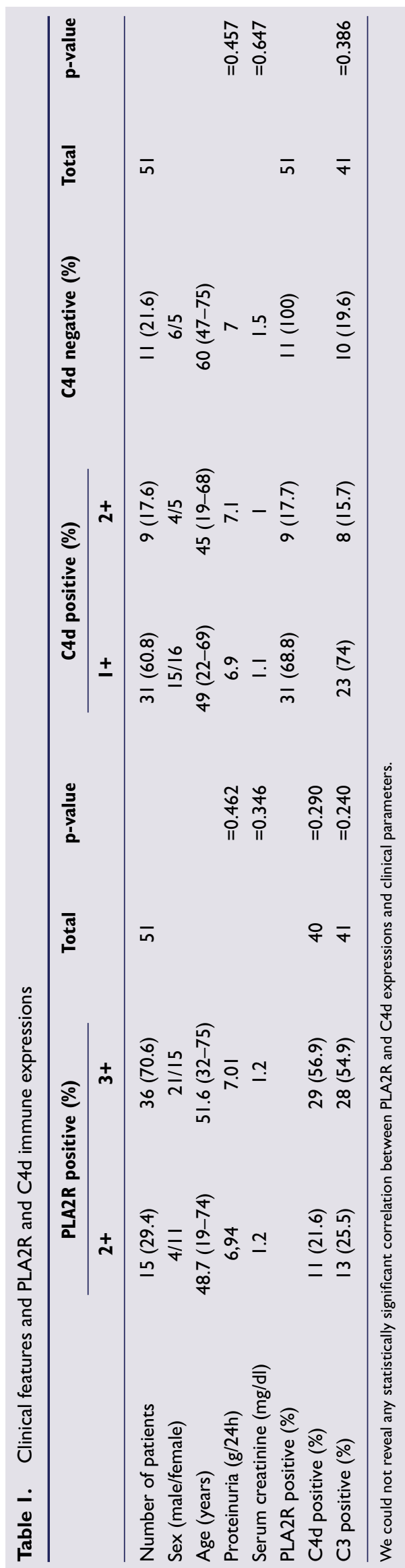



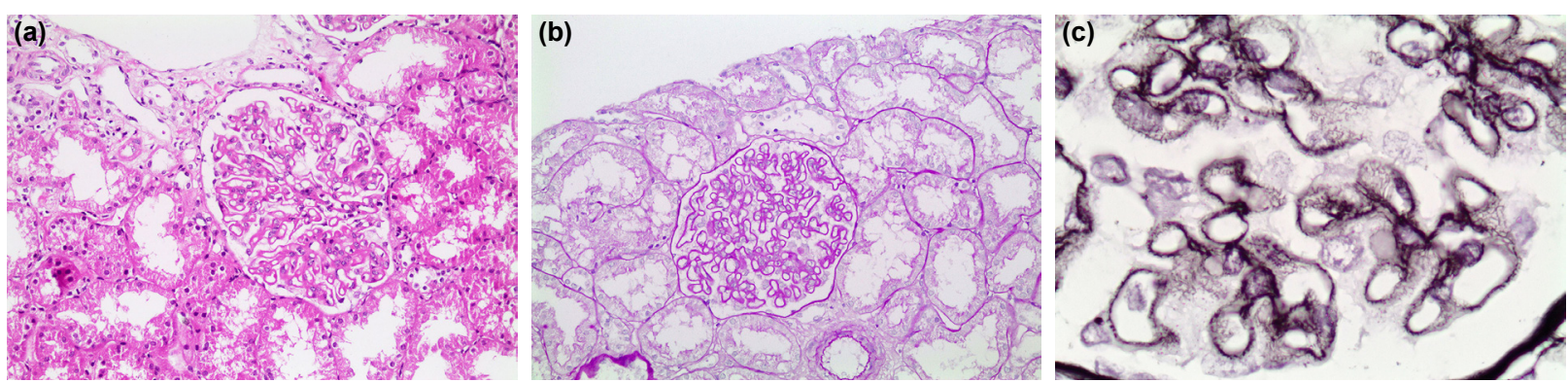

Figure 1. (a) Diffuse thickening of basal membranes of glomerulus (H\&E, $\times 200)$. (b) Thickened basement membranes are more prominent with PAS stain (PAS, $\times 200)$. (c) "Spike"structures are seen through the basement membranes (Gomori PAMS, $\times 1000)$.

The immunohistochemistry scoring results for PLA2R and C4d were based on the staining intensity of the glomerular basement membrane; no reactivity was defined as a score of 0 ; faint reactivity was defined as a score of $\mathrm{I}+$; moderate reactivity was defined as a score of $2+$; strong reactivity was defined as a score of $3+$. For PLA2R, a score of 0 or I+ was considered negative because of the faint PLA2R immunoexpression of the normal glomerulus.

\section{Statistical analysis}

Statistical analysis was carried out using NCSS (Number Cruncher Statistical System) 2007 Statistical Software (Utah, USA). Kruskal-Wallis and Mann-Whitney $U$ tests were used to compare the two groups. We analyzed the correlation between the expression of PLA2R and C4d in the PMN cases and the control tissues. Statistical comparisons between the intensity of the staining of PLA2R and C4d with varying degrees of proteinuria were performed using the Kruskal-Wallis and Mann-Whitney $U$ tests. A Pvalue of $<0.05$ was considered to be statistically significant.

\section{RESULTS}

In this study, 5 I paraffin blocks of PMN, 10 normal kidney tissues, and 10 FSGS cases were examined for the expression of PLA2R and C4d. All of the control cases ( 10 normal kidney tissues and I0 FSGS cases) (100\%) were negative for PLA2R (Fig. 2a). All 5 I (I00\%) of the PMN cases were positive for PLA2R in a fine granular pattern, including 15 (29\%) that scored 2+ (Fig. 2b) and $36(71 \%)$ that scored 3+ (Fig. 2c).

All of the control cases ( 10 normal kidney tissue and 10 FSGS cases) (100\%) were negative for C4d. Of the 5 I cases, 40 (78\%) cases were positive for C4d. The percentages of cases staining positively for $\mathrm{C} 4 \mathrm{~d}$, per scoring group, were as follows: 31 (6I\%) faintly $(I+)$ positive (Fig. 3a) and $9(18 \%)$ moderately $(2+)$ positive (Fig. 36$)$. No strong positivity was observed.

There was no statistically significant difference between the intensity of the staining of PLA2R and staining of C4d $(p=0.290)$, proteinuria levels $(p=0.462)$, creatinine levels $(p=0.346)$, and $C 3$ positivity $(p=0.240)$. Similarly, there was no statistically significant difference between the intensity of the staining of $C 4 d$ and proteinuria levels $(p=0.457)$, creatinine levels $(p=0.647)$, and C3 positivity $(p=0.386)$ (Table I).

\section{DISCUSSION}

PLA2R is a huge transmembrane glycoprotein with a molecular mass of $180-200 \mathrm{kDa}$ on the podocyte membrane. ${ }^{[8,30]}$ Autoantibodies against PLA2R are responsible for immune complex formation and deposition on the outer aspect of the glomerular basement membrane, which results in membranous nephropathy. ${ }^{[8]}$

The process of occurrence of autoantibodies against PLA2R, through immune complex formation and deposition on the glomerular basement membrane, can be used in different stages with different techniques for the diagnosis of PMN. Autoantibodies in serum can be detected with a Western blotting assay, ${ }^{[8,12,13,23,25,31,32]}$ enzyme-linked immunosorbent assay (ELISA), $[, 16,17,24,25,27,28,31,33]$ addressable laser bead immunoassay (ALBIA), ${ }^{[16]}$ and indirect immunofluorescence assay. ${ }^{[3,5,6,9,10,16,17,3,3,3,34]}$ In fresh and paraffin-embedded tissue, a direct immunofluorescence assay, ${ }^{[1,18,35]}$ and in paraffin-embedded tissue, immunohis-
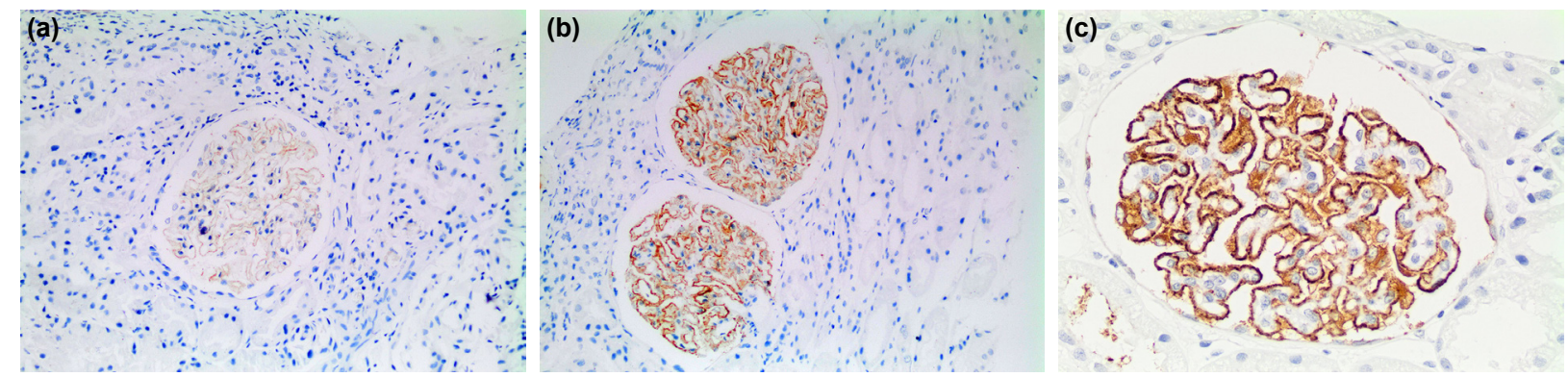

Figure 2. (a) Faint immune expression for PLA2R in normal glomeruli (Immunohistochemistry, $\times 200)$. (b) Moderate (2+) immune reactivity for PLA2R (Immunohistochemistry, $\times 200$ ). (c) Strong (3+) immune reactivity for PLA2R (Immunohistochemistry, $\times 400)$. 

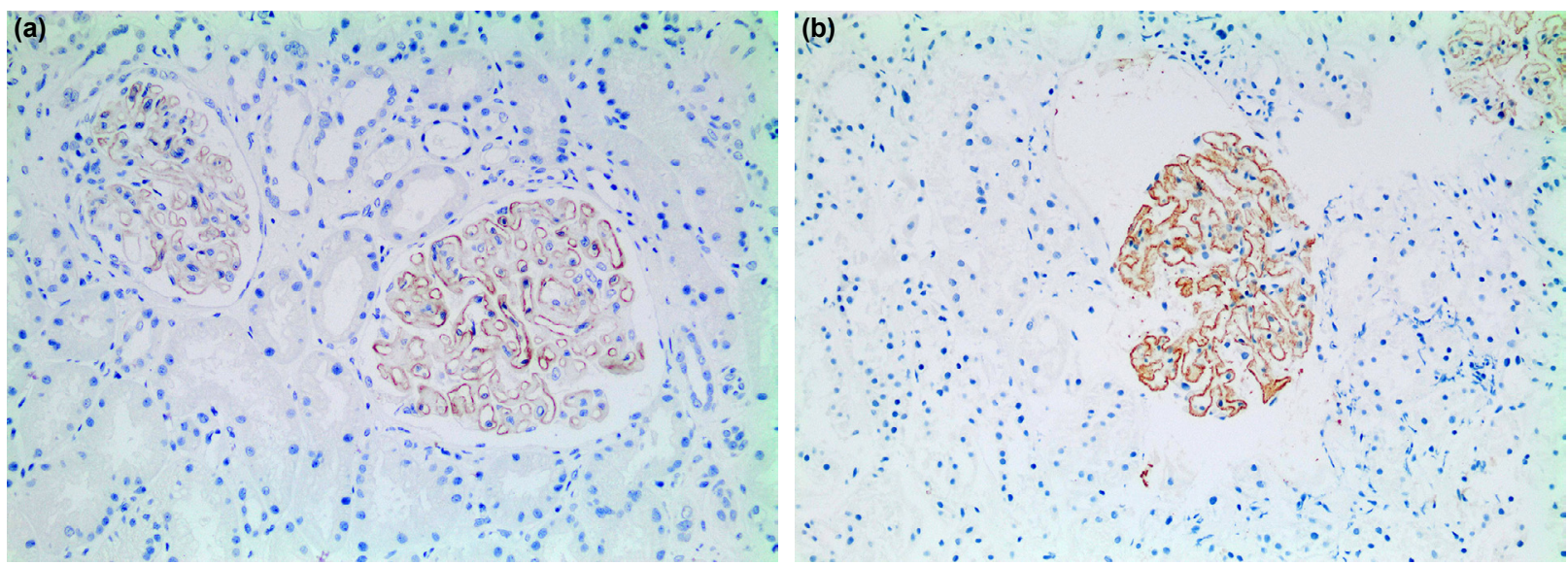

Figure 3. (a) Faint (1+) immune reactivity for C4d (Immunohistochemistry, $\times 200)$. (b) Moderate $(2+)$ immune reactivity for C4d (Immunohistochemistry, $\times 200)$.

tochemistry ${ }^{[3,17]}$ techniques can be used for the detection of glomerular immune deposits in PMN.

The sensitivity of detection of serum levels of PLA2R autoantibodies in different studies varies between $53-97 \%$. $[1,3,5,8-10,12,13,16,17,23-25,27,28,31-34]$ The detection of PLA2R in tissue by immunofluorescence varies between $45-83 \%$. $[1,18,35]$ There are few studies that evaluate PLA2R in PMN with immunohistochemistry. However, in these studies, sensitivity varies between $77-84 \% .^{[3,17]}$

The results of our study demonstrate that the detection of PLA2R immune complexes in tissue using immunohistochemistry could be a more sensitive method than immunofluorescence and serum detection methods in the diagnosis of PMN.

In comparison to the literature, there was an increased positivity for PLA2R in our PMN cases. This result might be related to the detailed investigation of the secondary causes of MN at our university hospital. In other words, the negativity for PLA2R in the literature may be due to the overlooking of cases with secondary MN.

Immune complex formation in PMN also causes complement activation. C4d is a $44.5 \mathrm{kD}$ fragment of $\mathrm{C} 4$, which is generated during the activation of the classical complement pathways. ${ }^{[19-22,36]}$ It has been demonstrated that the presence of C4d in peritubular capillaries is valuable for distinguishing acute humoral rejection from acute cellular rejection in kidney transplantation cases. There are a small number of studies investigating the presence of $\mathrm{C} 4 \mathrm{~d}$ in PMN. ${ }^{[19-22]}$ In these studies, it has been demonstrated that there is a deposition of $\mathrm{C} 4 \mathrm{~d}$ in the glomeruli in PMN. The percentage of deposition of C4d in the glomeruli was determined using the immunofluorescence method, in PMN cases are between $92-100 \%{ }^{[19,20]}$ However, the immunohistochemistry method presents this percentage as $100 \%{ }^{[21,22]}$ in these studies. Our study has revealed this percentage as $78 \%$, which is less than the literature.

There are some studies evaluating the relation between proteinuria and the severity of disease, and the presence of PLA2R autoantibodies in PMN..$^{[1,9,23-29]}$ The correlation between proteinuria and the severity of disease and the presence of PLA2R autoantibodies, has been demonstrated in these studies. However, to our knowledge, there is no study investigating the relation between proteinuria and the severity of disease and the presence of C4d in the glomeruli. Also, there is no study in the English literature that compares the levels of proteinuria and the severity of disease with the intensity of immunohistochemical staining of PLA2R and C4d.

In our study, we have not demonstrated a significant relation with the immunohistochemical method between the intensity of the staining of PLA2R and C4d, and proteinuria at the time of biopsy. Longer follow-up periods for proteinuria levels (3-6 months) may provide more accurate information about this relationship. In conclusion, immunohistochemical detection of PLA2R and C4d is a safe and easy method for the diagnosis of PMN. In cases where fresh tissue is not available for the detection of $\lg G$ and $C 3$ by the immunofluorescence method, positivity for PLA2R and C4d using immunohistochemistry may be beneficial for the diagnosis of the PMN.

To detect the significance of staining intensity in disease severity and prognosis, further studies with long-term follow-up data should be designed.

Funding

This study was funded by “ Marmara Üniversitesi Bilimsel Araştırma Projeleri Birimi”.

Ethics Committee Approval

All procedures performed in studies involving human participants were in accordance with the ethical standards of the institutional and/or national research committee and with the 1964 Helsinki Declaration and its later amendments or comparable ethical standards. This study was approved by the local ethics committee (date: 23.02.2015, no: 2).

Informed Consent

Retrospective study.

Peer-review

Internally peer-reviewed. 


\section{Authorship Contributions}

Concept: D.F., H.A., M.K., H.K., I.Ç.Ö., G.A.; Design: D.F., H.A., M.K., H.K., I..Ç.Ö., G.A.; Supervision: D.F., H.K.; Fundings: D.F., H.K.; Materials: D.F., G.A., M.K.; Data: D.F., G.A., H.A.; Analysis: D.F., H.A., H.K., M.K.; Literature search:D.F., H.A., H.K., i.Ç.Ö.; Writing: D.F.; Critical revision: i.Ç.Ö., H.K., H.A.

\section{Conflict of Interest}

None declared.

\section{REFERENCES}

1. Hoxha E, Harendza S, Pinnschmidt H, Panzer U, Stahl RA. PLA2R antibody levels and clinical outcome in patients with membranous nephropathy and non-nephrotic range proteinuria under treatment with inhibitors of the renin-angiotensin system. PLoS One 2014;9:e110681. [CrossRef]

2. Ronco P, Debiec H. Pathophysiology of extramembranous glomerulopathies. Fifty years of progress, from laboratory to patient. [Article in French] Biol Aujourdhui 2013;207:249-59. [CrossRef]

3. Hoxha E, Kneißler U, Stege G, Zahner G, Thiele I, Panzer U, et al. Enhanced expression of the M-type phospholipase A2 receptor in glomeruli correlates with serum receptor antibodies in primary membranous nephropathy. Kidney Int 2012;82:797-804. [CrossRef]

4. Bomback AS, Gharavi AG. Can genetics risk-stratify patients with membranous nephropathy?. J Am Soc Nephrol 2013;24:1190-2.

5. Debiec H, Hanoy M, Francois A, Guerrot D, Ferlicot S, Johanet $C$, et al. Recurrent membranous nephropathy in an allograft caused by $\operatorname{IgG} 3 \kappa$ targeting the PLA2 receptor. J Am Soc Nephrol 2012;23:1949-54. [CrossRef]

6. Larsen CP, Messias NC, Silva FG, Messias E, Walker PD. Determination of primary versus secondary membranous glomerulopathy utilizing phospholipase A2 receptor staining in renal biopsies. Mod Pathol 2013;26:709-15. [CrossRef]

7. Ronco P, Debiec H. Molecular pathomechanisms of membranous nephropathy: from Heymann nephritis to alloimmunization. J Am Soc Nephrol 2005;16:1205-13. [CrossRef]

8. Beck LH Jr, Bonegio RG, Lambeau G, Beck DM, Powell DW, Cummins TD, et al. M-type phospholipase A2 receptor as target antigen in idiopathic membranous nephropathy. N Engl J Med 2009;361:11-21.

9. Kozioł M, Sikora A, Kozioł-Montewka M, Smarz-Widelska I, Orłowska-Kowalik G, Pyszna W, et al. Preliminary results of research on a new marker of idiopathic membranous nephropathy: anti-PLA2R. Pol Merkur Lekarski 2014;36:171-4.

10. Svobodova B, Honsova E, Ronco P, Tesar V, Debiec H. Kidney biopsy is a sensitive tool for retrospective diagnosis of PLA2R-related membranous nephropathy. Nephrol Dial Transplant 2013;28:1839-44.

11. Debiec H, Ronco P. PLA2R autoantibodies and PLA2R glomerular deposits in membranous nephropathy. N Engl J Med 2011;364:68990. [CrossRef]

12. Qin W, Beck LH Jr, Zeng C, Chen Z, Li S, Zuo K, et al. Anti-phospholipase $\mathrm{A} 2$ receptor antibody in membranous nephropathy. J Am Soc Nephrol 2011;22:1137-43. [CrossRef]

13. Akiyama S, Akiyama M, Imai E, Ozaki T, Matsuo S, Maruyama S. Prevalence of anti-phospholipase A2 receptor antibodies in Japanese patients with membranous nephropathy. Clin Exp Nephrol 2015;19:653-60. [CrossRef]

14. Hayashi N, Akiyama S, Okuyama H, Matsui Y, Adachi H, Yamaya $\mathrm{H}$, et al. Clinicopathological characteristics of M-type phospholipase A2 receptor (PLA2R)-related membranous nephropathy in Japanese. Clin Exp Nephrol 2015;19:797-803. [CrossRef]
15. Du Y, Li J, He F, Lv Y, Liu W, Wu P, et al. The diagnosis accuracy of PLA2R-AB in the diagnosis of idiopathic membranous nephropathy: a meta-analysis. PLoS One 2014;9:e104936. [CrossRef]

16. Behnert A, Schiffer M, Müller-Deile J, Beck LH Jr, Mahler M, Fritzler MJ. Antiphospholipase $\mathrm{A}_{2}$ receptor autoantibodies: a comparison of three different immunoassays for the diagnosis of idiopathic membranous nephropathy. J Immunol Res 2014;2014:143274. [CrossRef]

17. Segarra-Medrano A, Jatem-Escalante E, Quiles-Pérez MT, Salcedo MT, Arbós-Via MA, Ostos H, et al. Prevalence, diagnostic value and clinical characteristics associated with the presence of circulating levels and renal deposits of antibodies against the M-type phospholipase $\mathrm{A} 2$ receptor in idiopathic membranous nephropathy. Nefrologia 2014;34:353-9.

18. Cossey LN, Walker PD, Larsen CP. Phospholipase A2 receptor staining in pediatric idiopathic membranous glomerulopathy. Pediatr Nephrol 2013;28:2307-11. [CrossRef]

19. Kusunoki Y, Itami N, Tochimaru H, Takekoshi Y, Nagasawa S, Yoshiki T. Glomerular deposition of C4 cleavage fragment (C4d) and C4-binding protein in idiopathic membranous glomerulonephritis. Nephron 1989;51:17-9. [CrossRef]

20. Val-Bernal JF, Garijo MF, Val D, Rodrigo E, Arias M. C4d immunohistochemical staining is a sensitive method to confirm immunoreactant deposition in formalin-fixed paraffin-embedded tissue in membranous glomerulonephritis. Histol Histopathol 2011;26:1391-7.

21. Espinosa-Hernández M, Ortega-Salas R, López-Andreu M, GómezCarrasco JM, Pérez-Sáez MJ, Pérez-Seoane C, et al. C4d as a diagnostic tool in membranous nephropathy. Nefrologia 2012;32:295-9.

22. Hui M, Uppin MS, Prayaga AK, Raju SB, Rajasekhar L. C4d immunohistochemistry in membranous nephropathy. J Lab Physicians 2014;6:76-9. [CrossRef]

23. Hofstra JM, Beck LH Jr, Beck DM, Wetzels JF, Salant DJ. Antiphospholipase $\mathrm{A}_{2}$ receptor antibodies correlate with clinical status in idiopathic membranous nephropathy. Clin J Am Soc Nephrol 2011;6:1286-91. [CrossRef]

24. Bech AP, Hofstra JM, Brenchley PE, Wetzels JF. Association of anti$\mathrm{PLA}_{2} \mathrm{R}$ antibodies with outcomes after immunosuppressive therapy in idiopathic membranous nephropathy. Clin J Am Soc Nephrol 2014;9:1386-92. [CrossRef]

25. Kanigicherla D, Gummadova J, McKenzie EA, Roberts SA, Harris S, Nikam M, et al. Anti-PLA2R antibodies measured by ELISA predict long-term outcome in a prevalent population of patients with idiopathic membranous nephropathy. Kidney Int 2013;83:940-8.

26. Hoxha E, Harendza S, Pinnschmidt H, Panzer U, Stahl RA. Mtype phospholipase A2 receptor autoantibodies and renal function in patients with primary membranous nephropathy. Clin J Am Soc Nephrol 2014;9:1883-90. [CrossRef]

27. Hoxha E, Thiele I, Zahner G, Panzer U, Harendza S, Stahl RA. Phospholipase A2 receptor autoantibodies and clinical outcome in patients with primary membranous nephropathy. J Am Soc Nephrol 2014;25:1357-66. [CrossRef]

28. Segarra-Medrano A, Jatem-Escalante E, Carnicer-Cáceres C, AgrazPamplona I, Salcedo MT, Valtierra N, et al. Evolution of antibody titre against the $\mathrm{M}$-type phospholipase $\mathrm{A} 2$ receptor and clinical response in idiopathic membranous nephropathy patients treated with tacrolimus. [Article in English, Spanish] Nefrologia 2014;34:491-7

29. Seitz-Polski B, Payré C, Ambrosetti D, Albano L, Cassuto-Viguier E, Berguignat $M$, et al. Prediction of membranous nephropathy recurrence after transplantation by monitoring of anti-PLA2R1 (Mtype phospholipase $\mathrm{A} 2$ receptor) autoantibodies: a case series of 15 patients. Nephrol Dial Transplant 2014;29:2334-42. [CrossRef]

30. Hanasaki K. Mammalian phospholipase A2: phospholipase A2 receptor. Biol Pharm Bull 2004;27:1165-7. [CrossRef] 
31. Timmermans SA, Damoiseaux JG, Heerings-Rewinkel PT, Ayalon $\mathrm{R}$, Beck LH Jr, Schlumberger W, et al. Evaluation of anti-PLA2R1 as measured by a novel ELISA in patients with idiopathic membranous nephropathy: a cohort study. Am J Clin Pathol 2014;142:29-34.

32. Oh YJ, Yang SH, Kim DK, Kang SW, Kim YS. Autoantibodies against phospholipase A2 receptor in Korean patients with membranous nephropathy. PLoS One 2013;8:e62151. [CrossRef]

33. Hofstra JM, Debiec H, Short CD, Pellé T, Kleta R, Mathieson PW, et al. Antiphospholipase A2 receptor antibody titer and subclass in idiopathic membranous nephropathy. J Am Soc Nephrol 2012;23:173543. [CrossRef]
34. Ardalan M, Ghafari A, Hamzavi F, Nasri H, Baradaran B, Majidi J, et l. Anti-phospholipase A2 receptor antibody in idiopathic membranous nephropathy: A report from Iranian population.J Nephropathol 2013;2:241-8.

35. Larsen CP, Walker PD. Phospholipase A2 receptor (PLA2R) staining is useful in the determination of de novo versus recurrent membranous glomerulopathy. Transplantation 2013;95:1259-62. [CrossRef]

36. Collins AB, Schneeberger EE, Pascual MA, Saidman SL, Williams WW, Tolkoff-Rubin N, et al. Complement activation in acute humoral renal allograft rejection: diagnostic significance of $\mathrm{C} 4 \mathrm{~d}$ deposits in peritubular capillaries. J Am Soc Nephrol 1999;10:2208-14.

\section{Primer Membranöz Nefropati Olgularında Fosfolipaz A2 Reseptör ve Kompleman 4d Ekspresyonunun Yoğunluğu}

Amaç: Primer membranöz nefropatide (PMN), podosit membranlarındaki fosfolipaz A2 reseptörüne (PLA2R) karşı gelişen antikorlar, immün komplekslerin oluşumuna neden olarak glomerular bazal membranda fonksiyon kaybına sebep olurlar. Ayrıca PMN'de glomerüllerde kompleman 4d (C4d) birikimi de gösterilmiştir. Bu çalışmanın amacı, PMN olgularında PLA2R ve C4d ekspresyonlarını değerlendirmek ve klinik parametrelerle bağlantılarını araştırmaktır.

Gereç ve Yöntem: Elli bir hastaya ait klinikopatolojik bilgiler ve parafine gömülmüş örnekleri toplandı. Formalin fikse ve parafine gömülmüş dokular rutin hematoksilen-eozin, periyodik asit schiff ve gümüş methenamin boyalarıly ve anti-PLA2R (CL0474; Atlas Antikorları) ve C4d (Poliklonal; CellMarque) immün boyalarıyla boyandı. On adet normal böbrek dokusu ve 10 adet fokal segmental glomeruloskleroz (FSGS) olgusu PLA2R ve C4d ekspresyonu için kontrol olarak seçildi.

Bulgular: PMN olgularının hepsi ( $n=5$ I) (\% I00) PLA2R ile pozitifti, I5'i (\%29) 2+, 36’sı (\%7I) 3+ olarak skorlandı. Olguların 40' । (\%78) C4d pozitifti. C4d boyanma oranları: 3 I olguda zayıf pozitif $(I+)(\% 6 I)$, dokuz olguda orta şiddette pozitif $(2+)(\% \mid 8)$ olarak gözlendi. Kuvvetli boyanma gözlenmedi. Tüm kontrol olguları PLA2R ve C4d ile negatifti. PLA2R ve C4d boyanma yoğunluğu ile proteinüri seviyeleri, kreatinin seviyeleri ve kompleman 3 (C3) pozitifliği arasında istatistiksel olarak anlamlı bir fark saptanmadı. Benzer olarak C4d boyanma yoğunluğu ile proteinüri seviyeleri, kreatinin seviyeleri ve C3 pozitifliği arasında istatistiksel anlamlı bir fark saptanmadı.

Sonuç: PMN tanısında PLA2R ve C4d'nin immünohistokimyasal olarak saptanması güvenli ve kolay bir metoddur. İmmünfloresan yöntemiyle IgG ve C3 saptanmasını sağlayacak yeterli dokunun olmadığı durumlarda, immünhistokimyasal olarak PLA2R ve C4d pozitifliği PMN tanısında faydalı olabilir.

Anahtar Sözcükler: C4d; membranöz; PLA2R; proteinüri. 